\title{
Erratum to: Investigating the mobilome in clinically important lineages of Enterococcus faecium and Enterococcus faecalis
}

Theresa Mikalsen ${ }^{1,10^{*}}$, Torunn Pedersen ${ }^{2}$, Rob Willems ${ }^{3}$, Teresa M. Coque ${ }^{4,5}$, Guido Werner ${ }^{6}$, Ewa Sadowy ${ }^{7}$, Willem van Schaik ${ }^{3}$, Lars Bogø Jensen ${ }^{8}$, María Victoria Francia ${ }^{9}$, Arnfinn Sundsfjord ${ }^{1,2}$ and Kristin Hegstad ${ }^{1,2}$

Erratum to: BMC Genomics doi:10.1186/s12864-015-1407-6

Following publication of this article it was brought to our attention that María Victoria Francia who contributed in the design of the array and provided target sequences was not included as an author.

\section{Authors' contributions \\ TM selected and prepared the targets sequences, collected the strains from the coauthors and hosting laboratory, performed the microarray and PCRs, contributed in analyzing and interpretation of the data and writing the manuscript. TP contributed in the design of the experiment, interpretation of data and substantially contributed to writing the manuscript. RW, TC and GW contributed in the design of the assay, provided target sequences, strains and contributed in writing the manuscript. ES contributed in the design, with strains and in the writing of the manuscript. WVS and LBJ provided targets sequences and contributed in writing the manuscript. AS and KH contributed in the design of the assay, interpretation and analyzing of the data and writing the manuscript}

Authors' information

Arnfinn Sundsfjord and Kristin Hegstad are joined senior authors.

\section{Author details}

${ }^{1}$ Research group for Host-microbe Interactions, Department of Medical Biology, Faculty of Health Science, University of Troms $\varnothing$ - The Arctic University of Norway, Tromsø, Norway. ${ }^{2}$ Department of Microbiology and Infection Control, University Hospital of North Norway, Tromsø, Norway. ${ }^{3}$ Department of Medical Microbiology, University Medical Center Utrecht, Utrecht, The Netherlands. ${ }^{4}$ Servicio de Microbiologia, Hospital Ramón y Cajal, Instituto Ramón y Cajal de Investigación Sanitaria (IRYCIS), Madrid, Spain. ${ }^{5}$ Centro de Investigación Biomédica en Red de Epidemiología y Salud Pública (CIBER-ESP), Madrid, Spain. ${ }^{6}$ Division of Nosocomial Pathogens and Antibiotic Resistance, Robert Koch Institute, Wernigerode Branch, Wernigerode, Germany. ${ }^{7}$ Department of Molecular Microbiology, National Medicines Institute, ul. Chełmska 30/34, 00-725 Warsaw, Poland. ${ }^{8}$ Division of Food Microbiologyt, National Food Institute, Danish Technical University, Copenhagen V, Denmark. ${ }^{9}$ Servicio de Microbiología, Pabellón 20, Hospital Universitario Marqués de Valdecilla e Instituto de Investigación Marqués de Valdecilla, Av. Valdecilla s/n. 39008, Santander, Spain. ${ }^{10}$ Theresa Mikalsen and Kristin Hegstad, UiT The Arctic University of Norway, Postbox 6050 Langnes 9037 Troms $\varnothing$, Norway.

Received: 24 June 2015 Accepted: 26 June 2015

Published online: 15 September 2015

\footnotetext{
* Correspondence: Theresa.Mikalsen@uit.no

${ }^{1}$ Research group for Host-microbe Interactions, Department of Medical Biology, Faculty of Health Science, University of Troms $\varnothing$ - The Arctic University of Norway, Tromsø, Norway

${ }^{10}$ Theresa Mikalsen and Kristin Hegstad, UiT The Arctic University of Norway, Postbox 6050 Langnes 9037 Tromsø, Norway

Full list of author information is available at the end of the article
}

\section{Submit your next manuscript to BioMed Central and take full advantage of:}

- Convenient online submission

- Thorough peer review

- No space constraints or color figure charges

- Immediate publication on acceptance

- Inclusion in PubMed, CAS, Scopus and Google Scholar

- Research which is freely available for redistribution

Submit your manuscript at www.biomedcentral.com/submit

\section{() Biomed Central}

(c) 2015 Mikalsen et al. This is an Open Access article distributed under the terms of the Creative Commons Attribution License (http://creativecommons.org/licenses/by/4.0), which permits unrestricted use, distribution, and reproduction in any medium, provided the original work is properly credited. The Creative Commons Public Domain Dedication waiver (http:// creativecommons.org/publicdomain/zero/1.0/) applies to the data made available in this article, unless otherwise stated. 